\title{
A Potassium-Selective Current Affected by Micromolar Concentrations of Anion Transport Inhibitors
}

\author{
Roberta Costa ${ }^{a}$ Davide Antonio Civello ${ }^{a}$ Emanuele Bernardinellia \\ Simone Vanoni ${ }^{b} \quad$ Michaela Zopf ${ }^{b} \quad G^{2}$ iada Scantamburlob Charity Nofziger ${ }^{b}$ \\ Wolfgang Patscha Markus Paulmichlc Silvia Dossena ${ }^{\mathrm{a}}$ \\ aInstitute of Pharmacology and Toxicology, Paracelsus Medical University, Salzburg, ${ }^{b}$ PharmGenetix \\ Gmbh, Sonystrasse 20, Niederalm-Anif, 'Center for Health and Bioresources, Austrian Institute of \\ Technology (AIT), Vienna, Austria
}

\section{Key Words}

Voltage-dependent outwardly rectifying potassium channels - Swelling-activated chloride current • NPPB • DIDS • Niflumic acid • ICl,swell • Kv 3.1

\begin{abstract}
Background/Aims: In the human genome, more than 400 genes encode ion channels, which are ubiquitously expressed and often coexist and participate in almost all physiological processes. Therefore, ion channel blockers represent fundamental tools in discriminating the contribution of individual channel types to a physiological phenomenon. However, unspecific effects of these compounds may represent a confounding factor. Three commonly used chloride channel inhibitors, i.e. 4,4'-diisothiocyano-2,2'-stilbene-disulfonic acid (DIDS), 5-nitro2-[(3-phenylpropyl) amino]benzoic acid (NPPB) and the anti-inflammatory drug niflumic acid were tested to identify the lowest concentration effective on $\mathrm{Cl}^{-}$channels and ineffective on $\mathrm{K}^{+}$ channels. Methods: The activity of the above mentioned compounds was tested by whole cell patch-clamp on the swelling-activated $\mathrm{Cl}^{-}$current $\mathrm{ICl}$,swell and on the endogenous voltagedependent, outwardly rectifying $\mathrm{K}^{+}$selective current in human kidney cell lines (HEK 293/HEK

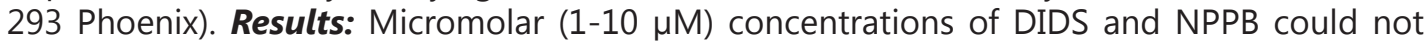
discriminate between the $\mathrm{Cl}^{-}$and $\mathrm{K}^{+}$selective currents. Specifically, $1 \mu \mathrm{M}$ DIDS only affected the $\mathrm{K}^{+}$current and $10 \mu \mathrm{M}$ NPPB equally affected the $\mathrm{Cl}^{-}$and $\mathrm{K}^{+}$currents. Only relatively high (0.1-1 mM) concentrations of DIDS and prolonged (5 minutes) exposure to 0.1-1 mM NPPB preferentially suppressed the $\mathrm{Cl}^{-}$current. Niflumic acid preferentially inhibited the $\mathrm{Cl}^{-}$current, but also significantly affected the $\mathrm{K}^{+}$current. The endogenous voltage-dependent, outwardly rectifying $\mathrm{K}^{+}$selective current in HEK 293/HEK 293 Phoenix cells was shown to arise from the Kv 3.1 channel, which is extensively expressed in brain and is involved in neurological diseases. Conclusion: The results of the present study underscore that sensitivity of a given physiological
\end{abstract}




\section{Cellular Physiology Cell Physiol Biochem 2018;45:867-882 \\ \begin{tabular}{ll|l} 
and Biochemistry Published online: February 08, 2018 & $\begin{array}{l}\text { (c) } 2018 \text { The Author(s). Published by S. Karger AG, Basel } \\
\text { www.karger.com/cpb }\end{array}$ \\
\hline
\end{tabular} \\ Costa et al.: Kv 3.1 and Chloride Channel Blockers}

phenomenon to the $\mathrm{Cl}^{-}$channel inhibitors NPPB, DIDS and niflumic acid may actually arise from an inhibition of $\mathrm{Cl}^{-}$channels but can also result from an inhibition of voltage-dependent $\mathrm{K}^{+}$channels, including the Kv 3.1 channel. The use of niflumic acid as anti-inflammatory drug in patients with concomitant Kv 3.1 dysfunction may result contraindicated.

(C) 2018 The Author(s)

Published by S. Karger AG, Basel

\section{Introduction}

Pharmacological inhibition plays a fundamental role in discriminating the contribution of distinct ion transport systems to measureable phenomena, including macroscopic currents, differences of potential across plasma or epithelial membranes, salt reabsorption or secretion, and cardiac or nerve action potentials. However, unspecific effects of ion transport inhibitors may represent a confounding factor. In this regard, chloride channel blockers are recognized to variably affect (either activate or inhibit) cation currents [1], including those from $\mathrm{Na}^{+}[2], \mathrm{K}^{+}[3,4], \mathrm{Ca}^{++}[5]$ and nonselective cation [6] channels.

Being involved in the determination of basic homeostatic functions, such as the difference of potential across the plasma membrane and the regulation of cellular volume, $\mathrm{K}^{+}$ and $\mathrm{Cl}^{-}$channels always coexist in a same tissue or cell type [7]. However, the discrimination between $\mathrm{K}^{+}$and $\mathrm{Cl}^{-}$currents is not always straightforward. $\mathrm{Cl}^{-}$channel blockers have been reported to exert various effects on $\mathrm{K}^{+}$currents, especially on voltage-dependent (Kv) channels, and specifically on cardiac $\mathrm{Ca}^{++}$-independent transient outward current $\mathrm{I}_{\text {to1 }}$, of which $\mathrm{Kv} 4.2 / 4.3$ are the underlying channels. $\mathrm{I}_{\text {to }}$ was found to be blocked by relatively high (2 mM) concentrations of disodium 4-acetamido-4'-isothiocyanato-stilben-2, 2' -disulfonate (SITS) [8]. Accordingly, 4, 4'-diisothiocyano-2, 2'-stilbene-disulfonic acid (DIDS) and SITS ( $\geq$ $10 \mu \mathrm{M}$ ) increased the time constant for recovery from inactivation of Kv 4.3 current, while niflumic and flufenamic acid $(\geq 30 \mu \mathrm{M})$ produced large shifts in the steady state inactivation curve, both effects leading to an apparent inhibition of the current [9]. Tamoxifen $(10 \mu \mathrm{M})$ and DIDS $(10 \mu \mathrm{M})$ inhibited a delayed rectifier $\mathrm{K}^{+}$current of $\sim 38$ and $\sim 10 \%$ respectively in canine colonic myocytes [10]. On the other hand, 5-nitro-2-[(3-phenylpropyl) amino] benzoic acid (NPPB; $25 \mu \mathrm{M})$ and niflumic acid $(50 \mu \mathrm{M})$ enhanced the delayed rectifier $\mathrm{K}^{+}$ current but inhibited $\mathrm{I}_{\text {to }}$ in rat ventricular myocytes [11].

Given that chloride channel blockers can also affect $\mathrm{K}^{+}$channels, and based on the common knowledge that increasing the concentration of a drug can lead to unspecific effects, three commonly used chloride channel blockers $(0.1 \mu \mathrm{M}-1 \mathrm{mM}$ DIDS and niflumic acid and $1 \mu \mathrm{M}-1 \mathrm{mM}$ NPPB) were tested to identify the lowest concentration effective on $\mathrm{Cl}^{-}$channels and ineffective on $\mathrm{K}^{+}$channels. The activity of the aforementioned compounds was assayed on the swelling-activated $\mathrm{Cl}^{-}$current $\mathrm{ICl}$,swell and on the endogenous voltage-dependent, outwardly rectifying $\mathrm{K}^{+}$selective current in a human kidney cell line.

$\mathrm{ICl}$,swell (also called ICl,vol) is the ubiquitous cell volume-sensitive chloride current, which is virtually absent or minimally activated in isotonic conditions and is strongly activated in response to extracellular hypotonicity. The biophysical properties of this current include mild outward rectification, iodide over chloride selectivity, and variable inactivation at positive potentials. ICl,swell is considered a major player in the process of regulatory volume decrease (RVD), a homeostatic reaction that reduces the cellular volume after anisosmotic cell swelling. RVD is achieved by the loss of intracellular $\mathrm{K}^{+}, \mathrm{Cl}^{-}$and osmotically active organic molecules, which then drives an obligated efflux of water from swollen cells, thereby reducing their volume. $\mathrm{ICl}$,swell has been proposed to induce both the $\mathrm{Cl}^{-}$and organic osmolytes efflux during RVD [12-15].

Voltage-dependent $\mathrm{K}^{+}\left(\mathrm{K}_{\mathrm{v}}\right)$ channels are a large and diverse group of ion channels that includes delayed rectifiers $\left(I_{K}\right)$, A-type $\left(I_{A}\right)$, outward rectifying, inwardly-rectifying, slowly activating $\alpha$ subunits, modifiers and regulatory $\beta$ subunits. The members of this family of channels present distinctive characteristics in terms of biophysical and pharmacological properties, tissue distribution and disease association. For example, delayed rectifiers (including the $S h a w$-related $\mathrm{Kv} 3.1 / \mathrm{Kv} 3.2$ channels, which are predominantly expressed in 


\section{Cellular Physiology Cell Physiol Biochem 2018;45:867-882 \begin{tabular}{l|l|l|l} 
DOI: 10.1159/000487282 & $\begin{array}{l}\text { O } 2018 \text { The Author(s). Published by S. Karger AG, Basel } \\
\text { www.karger.com/cpb }\end{array}$
\end{tabular} \\ Costa et al.: Kv 3.1 and Chloride Channel Blockers}

brain) are either slowly inactivating or non-inactivating, while A-type channels (including the Shal-related $\mathrm{Kv} 4.2 / \mathrm{Kv} 4.3$, which are mainly expressed in brain and heart) are rapidly inactivating $[16,17]$.

It was found here that micromolar (1-10 $\mu \mathrm{M})$ concentrations of DIDS and NPPB could not discriminate between the above-mentioned $\mathrm{Cl}^{-}$and $\mathrm{K}^{+}$currents. A preferential block of $\mathrm{Cl}^{-}$currents could be obtained either with 0.1-1 mM DIDS, $0.1 \mathrm{mM}$ niflumic acid or after prolonged (5 minutes) exposure to 0.1-1 mM NPPB.

\section{Materials and Methods}

\section{Cell culture}

Human embryonic kidney (HEK) 293 (CRL-1573, directly obtained from American Type Cell Culture Collection), HEK 293 Phoenix (this is a second-generation retrovirus producer line for the generation of helper free ecotropic and amphotropic retroviruses based on the 293T cell line [18]) and HeLa (human cervical adenocarcinoma, CCL-2, directly obtained from American Type Cell Culture Collection) cells were cultured in Minimum Essential Eagle Medium (Sigma-Aldrich, Austria) supplemented with 10\% fetal bovine serum (FBS; Gibco, MA, USA), 2 mM L-glutamine, $100 \mathrm{U} / \mathrm{ml}$ penicillin, $100 \mu \mathrm{g} / \mathrm{ml}$ streptomycin and $1 \mathrm{mM}$ pyruvic acid (sodium salt). NIH-3T3 cells (mouse fibroblasts, CRL-1658, directly obtained from American Type Cell Culture Collection) were cultured in Dulbecco's modified Eagle's Medium (Sigma-Aldrich, Austria) supplemented with $10 \%$ newborn bovine serum (Gibco), $100 \mathrm{U} / \mathrm{ml}$ penicillin and $100 \mathrm{\mu g} / \mathrm{ml}$ streptomycin.

Mouse primary renal proximal tubular epithelial cells were obtained from CD1 mice by microdissection. In brief, mice were sacrificed by cervical dislocation. Kidneys were immediately removed and placed in ice-cold Hanks Balanced Salt Solution (HBSS, Sigma-Aldrich, Austria). The renal capsule was removed and small slices from the cortex were prepared. Microdissection of proximal tubules from the cortical tissue was performed in cold $\left(4^{\circ} \mathrm{C}\right)$ HBSS containing bovine serum albumin ( $1 \mathrm{mg} / \mathrm{ml}$; Merck, Germany) under a stereomicroscope using forceps. Isolated proximal tubules were transferred into 96 well plates coated with a collagen (1, $3 \mathrm{mg} / \mathrm{ml}$; Sigma-Aldrich) and fibronectin (55 $\mu \mathrm{g} / \mathrm{ml}$; Sigma-Aldrich) matrix and cultured in Dulbecco's Modified Eagle Medium/F12 (Sigma-Aldrich, Austria) supplemented with 10\% FBS, 100 U/ $\mathrm{ml}$ penicillin, $100 \mu \mathrm{g} / \mathrm{ml}$ streptomycin, $5 \mu \mathrm{g} / \mathrm{ml}$ insulin, $5 \mu \mathrm{g} / \mathrm{ml}$ holo-transferrin, $5 \mathrm{ng} / \mathrm{ml}$ selenium, 36 $\mathrm{ng} / \mathrm{ml}$ hydrocortisone, $4 \mathrm{pg} / \mathrm{ml} \mathrm{T3}$ and $10 \mathrm{ng} / \mu \mathrm{l}$ epidermal growth factor. Epithelial cells from the tubules dissociated from the tubular structure over a span of 5-14 days and attached to the culture dish. Cells were then passaged onto successively larger culture areas for amplification. All experiments were performed in accordance to the guidelines of the "Directive 2010/63/EU of the European Parliament and of the Council of 22 September 2010 on the protection of animals used for scientific purposes" and were approved by the local animal care authorities.

The cells were maintained at $37{ }^{\circ} \mathrm{C}, 5 \% \mathrm{CO}_{2}, 95 \%$ air and $100 \%$ humidity. Except for kidney proximal tubule cells, subcultures were routinely established every second to third day by seeding the cells into 100 $\mathrm{mm}$ diameter Petri dishes following trypsin/ethylenediaminetetraacetic acid (EDTA) treatment. Kidney proximal tubule cells were subcultured once weekly and used between passages 4 to 7 . HeLa and NIH-3T3 cells were used between passages 2 to 20 .

\section{Cell transfection and plasmid vectors}

For transfection, NIH-3T3 cells were seeded into $35 \mathrm{~mm}$ diameter Petri dishes and grown overnight to $\sim 30 \%$ confluence. Cells were transfected with $3 \mu \mathrm{g}$ of plasmid DNA and $6 \mu \mathrm{l}$ of Metafectene Pro (Biontex, Germany) following the manufacturer's instructions. Control (mock transfected) cells were exposed to the transfection mixture with no plasmid DNA. The plasmid vector pcDNA3.1+P2A-eGFP coding for Kv 3.1 (KCNC1, NCBI Reference Sequence: NM_004976.4) was purchased from GenScript (USA). The self-cleaving 2A peptide (P2A) allows for the simultaneous expression of two individual proteins - Kv3.1 and eGFP — from a single bicistronic mRNA without the production of fusion proteins [19]. For patch-clamp, the single transfected cells could be individuated optically by detecting the fluorescent light emitted by eGFP (excitation maximum, $488 \mathrm{~nm}$; emission maximum, $507 \mathrm{~nm}$ ). Experiments were performed 24 hours after transfection. 


\section{Cellular Physiology Cell Physiol Biochem 2018:45:867-882

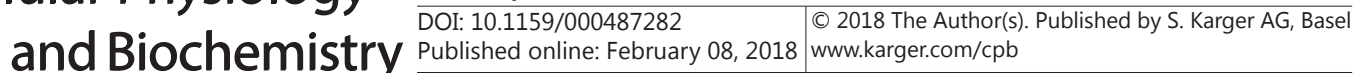

\section{Patch clamp experiments}

Cells for electrophysiology were seeded on glass coverslips (diameter, $10 \mathrm{~mm}$ ) contained in $30 \mathrm{~mm}$ diameter Petri dishes and grown overnight. Single cells were selected by phase contrast microscopy and voltage clamped using the whole-cell patch clamp technique as previously described [20-26]. To isolate chloride currents, bath solutions 1 and 2 and pipette solution 1 (Table 1) were used. The seal was realized and cells were initially kept in isotonic bath solution 1 . To activate the swelling-dependent chloride current (ICl,swell), a fast exchange of the isotonic with the hypotonic bath solution 2 was accomplished using a perfusion system with a flow rate of $5 \mathrm{ml} / \mathrm{min}$ and a bath volume of $\sim 300 \mu$ l. The cells were held at $0 \mathrm{mV}$, and step pulses of $400 \mathrm{~ms}$ duration were applied from $0 \mathrm{mV}$ to $+40 \mathrm{mV}$ every $20 \mathrm{~s}$ to monitor current changes over time. To establish the current-to-voltage (I/V) relationship, step pulses of $500 \mathrm{~ms}$ duration were applied from $-120 \mathrm{mV}$ to $+100 \mathrm{mV}$ in $20 \mathrm{mV}$ increments from a holding potential of $0 \mathrm{mV}$. The IV relationships were established every 5 minutes. To isolate potassium currents, bath solution 3 and pipette solution 2 (Table 1) were used. To establish the I/V relationship, step pulses of $500 \mathrm{~ms}$ duration were applied from $-120 \mathrm{mV}$ to $+100 \mathrm{mV}$ in 20 $\mathrm{mV}$ increments from a holding potential of $-60 \mathrm{mV}$.

The resistance of the glass pipettes filled with a pipette solution and immersed in a bath solution was 3 to $8 \mathrm{M} \Omega$. For data acquisition, EPC-10 and EPC-8 (HEKA Elektronik, Germany) amplifiers controlled by Macintosh computers running the Patch Master (HEKA Elektronik) software were used. The wholecell configuration was only obtained from stable seals of resistance not lower than $2-3 \mathrm{G} \Omega$ in cell-attached configuration (for glass electrodes not subjected to fire polishing). The limits of membrane resistance in whole-cell configuration and leak currents accepted to validate a recording were $1 \mathrm{G} \Omega$ and $+100 \mathrm{pA}$ at +100 $\mathrm{mV}$, respectively. These values refer to conditions where macroscopic currents were not activated, i.e. in extracellular isotonic solution for the $\mathrm{Cl}^{-}$current and at a holding potential of $-60 \mathrm{mV}$ for the $\mathrm{K}^{+}$current. Fast and slow capacitance were compensated and series resistance was monitored throughout the recordings. If the series resistance was higher than twice the resistance of the patch electrode at the beginning of a recording, or exceeded this value any time during a recording, the current measurement was not accepted. All current measurements were filtered at $5 \mathrm{kHz}$ and digitized at $50 \mathrm{kHz}$. For data analysis, Fit Master (HEKA Elektronik) and Excel (Microsoft, USA) software were used. Where indicated, the current values (pA) were normalized to the membrane capacitance $(\mathrm{pF})$ to obtain the current density $(\mathrm{pA} / \mathrm{pF})$, which is a measure of the current magnitude independent from the cell size. The subtraction of currents of leakage was not performed. All experiments were carried out at room temperature. Each independent experimental series was performed rigorously alternating one recording with the selected inhibitor and one recording with the respective vehicle over a time frame of no more than two weeks. The decay of potassium and chloride currents at $+100 \mathrm{mV}$ was best fitted with an exponential of the form

$I(t)=I_{p e a k} e^{-t / t}$

where Ipeak is the peak current and $\tau$ is the time constant of current inactivation.

Reverse Transcription-PCR (RT-PCR)

Extraction of total RNA from HEK 293, 293 Phoenix, HeLa, NIH-3T3 and primary proximal tubule cells was performed with the All Prep DNA/RNA mini kit (Qiagen, Germany) from cells grown to confluence on 


\section{Cellular Physiology Cell Physiol Biochem 2018;45:867-882 \begin{tabular}{l|l|l} 
and Biochemistry & $\begin{array}{l}\text { DOI: 10.1159/000487282 } \\
\text { Published online: February 08, } 2018\end{array}$ & $\begin{array}{l}\text { () } 2018 \text { The Author(s). Published by S. Karger AG, Basel } \\
\text { ww.karger.com/cpb }\end{array}$ \\
\hline
\end{tabular}

one 100 mm diameter Petri dish. Total RNA from human adult brain (Cat \# 540005-41, Lot \# 0006242610) was purchased from Agilent (USA). One $\mu \mathrm{g}$ of total RNA was used for the reverse transcription reaction with the QuantiTect $\AA$ reverse transcription kit for cDNA synthesis with integrated removal of genomic DNA contamination (Qiagen). For detecting the Kv 1.1, Kv 1.2, Kv 1.3, Kv 1.4, Kv 1.5, Kv 1.6, Kv 2.1 and $\mathrm{Kv} 3.1$ mRNAs, previously reported primers were used [27]. The $\beta$-actin signal was detected by using the following primers: forward, 5'-GGC ATG GGT CAG AAG GAT TC-3'; and reverse, 5'-AGA GGC GTA CAG GGA TAG CAC3'. These primers span an intron-exon boundary and would disclose contamination from genomic DNA as a band at $740 \mathrm{bp}$, which was not detected. To verify the identity of the signals that were detected (if any), the bands were extracted from the gel, purified with the MinElute Gel Extraction kit (Qiagen) and Sanger sequenced in the forward and reverse directions with the same primers used for amplification (Microsynth AG, Switzerland).

HEK 293 Phoenix and human adult brain were tested for the expression of Kv 3.1 transcripts. To discriminate between the long and short Kv 3.1 transcripts, a common forward primer (5'-GCC TCG AGA TGG GCC AAG GGG ACG AGA G-3') and two distinct reverse primers (5'-GCC GGA TCC TCA AGT CAC TCT CAC AGC CTC-3' and 5'-GGG GAT CCT TCA GAT CGA CAT GCC TCT AAG-3'for the long and short transcript, respectively) were used.

\section{Western Blot}

HEK 293 Phoenix cells seeded in each well of a 6-well plate were washed with phosphate buffered solution (PBS) and scraped in $50 \mu \mathrm{l}$ of ice-cold lysis buffer $(20 \mathrm{mM}$ Tris- $\mathrm{HCl} \mathrm{pH}$ 8, $150 \mathrm{mM} \mathrm{NaCl}, 1 \mathrm{mM}$ EDTA, 1\% NP40, 1X Halt Protease Inhibitor Cocktail, Thermo Scientific, MA, USA) on ice. Cell lysates were centrifuged at $16,000 \mathrm{xg}$ at $4{ }^{\circ} \mathrm{C}$ for 30 minutes. The supernatant was collected and stored at $-80{ }^{\circ} \mathrm{C}$ until use. Total protein extracts $(\geq 20 \mu \mathrm{g}$ ) were electrophoresed with constant voltage (120 V) on SDS-PAGE gels (7.5\%). Proteins were then transferred for 2 hours onto polyvinylidene fluoride (PVDF) membranes with constant voltage $(75 \mathrm{~V})$. The membranes were blocked for 1 hour at room temperature in 5\% nonfat dry milk diluted in Tris-buffered saline containing 0.01\% Tween 20, pH 7.6 (TBST). Afterwards, PVDF membranes were incubated overnight at $4{ }^{\circ} \mathrm{C}$ with primary antibodies diluted in TBST containing $5 \%$ nonfat dry milk, washed 3 times in TBST, incubated for 1 hour in the dark and at room temperature with the secondary antibody diluted in TBST containing 5\% nonfat dry milk, washed again and kept in TBST. Immunocomplexes were visualized using the ODYSSEY infrared imaging system (LICOR, NE, USA). The mouse monoclonal anti-Kv 3.1 (E-2) antibody (sc-514554, 1:100 dilution) was from Santa Cruz Biotechnology (TX, USA). The goat polyclonal anti-GAPDH antibody (JP_A00191-40, 1:1000 dilution) was from GenScript (NJ, USA). The anti-goat (926-32214, 1:10, 000 dilution) and anti-mouse (926-32210, 1:10, 000 dilution) IRDye $800 \mathrm{CW}$ secondary antibodies were from LICOR. Kv 3.1 signal was normalized for the signal of the housekeeping protein GAPDH. Densitometry was performed with ImageJ 1.46r software (Wayne Rasband, NIH, MD, USA).

\section{RNA Interference}

Small interfering (si) RNAs for knocking down the expression of Kv 3.1 (core sequence siRNA \#1: 5'GAA CUC GCU CAA CAU CAU U-3'; siRNA \#2: 5'-CGU UCG CAA UGG CAC GCA A-3'; siRNA \#3: 5'-CAA GGU AGA GUU CAU CAA G-3') were designed with the siRNA Design Tool of Microsynth. HEK 293 Phoenix cells seeded into $30 \mathrm{~mm}$ diameter Petri dishes were co-transfected with 180-360 pmol of siRNAs, $1 \mu \mathrm{g}$ of pEYFPN1 vector (Clontech, CA, USA) coding for the transfection marker enhanced yellow fluorescent protein EYFP and 24 $\mu \mathrm{l}$ of Metafectene SI (Biontex) following the manufacturer's instruction. Control cells were transfected with the following negative control siRNA (Microsynth), with no homologies with known sequences: 5'-AGG UAG UGU AAU CGC CUU GTT-3'. Functional (patch clamp) or expression (Western blot and semi-quantitative PCR) assays were performed 48-72 h after transfection. For patch clamp, single transfected cells were selected by fluorescence microscopy and voltage clamped using the whole-cell patch clamp technique as described above.

Salts and chemicals

4, 4'-diisothiocyano-2, 2'-stilbene-disulfonic acid (DIDS; D3514), 5-nitro-2-[(3-phenylpropyl)amino] benzoic acid (NPPB; N4779) and niflumic acid (N0630) were purchased from Sigma-Aldrich. Stock solutions $(0.1 \mathrm{M})$ were prepared in dimethyl sulfoxyde (DMSO) and stored at $-20{ }^{\circ} \mathrm{C}$ in the dark. All salts and chemicals used were of per analysis grade. 


\section{Cellular Physiology Cell Physiol Biochem 2018;45:867-882

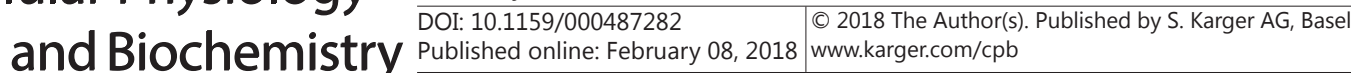 \\ Costa et al.: Kv 3.1 and Chloride Channel Blockers}

\section{Statistical Analysis}

All data were expressed as arithmetic means \pm S.E.M. For statistical analysis, GraphPad Prism software (version 4.00 for Windows, GraphPad Software, CA, USA) was used. Significant differences between data sets were tested by two-tailed, paired or unpaired Student's t test or two-way ANOVA with Bonferroni's ad hoc post test, as appropriate. Statistically significant differences between data sets were assumed at $\mathrm{p}<0.05$; (n) corresponds to the number of independent measurements.

\section{Results}

Chloride and potassium selective currents in HEK 293/293 Phoenix cells

Endogenous currents resembling the outwardly rectifying and voltage-dependent potassium currents of the Kv channel family can be found in HEK 293 Phoenix cells (Figs. 1A, $2 \mathrm{~A}$ and $3 \mathrm{~A}$ ). These currents are detectable in the whole-cell configuration of patch clamp, were found in HEK 293 cells but not in HeLa cells, NIH-3T3 cells or primary culture of mouse kidney tubule cells (data not shown).

HEK 293 Phoenix cells kept in an isotonic medium do not manifest $\mathrm{Cl}^{-}$currents detectable in the whole-cell configuration of patch clamp (Figs. 1B, 2B and 3B, isotonic). However, prominent activation of $\mathrm{Cl}^{-}$currents is seen after reduction of extracellular osmolarity (Figs. 1B, 2B and 3B, hypo SS).

Micromolar concentrations of DIDS, NPPB and niflumic acid modify the biophysical properties of a potassium selective current

In the range tested $(0.0001-1 \mathrm{mM})$, the lowest concentration of DIDS with a statistically significant inhibitory effect on $\mathrm{K}^{+}$currents was $0.001 \mathrm{mM}$ (Table 2). At this concentration, the effect of DIDS on $\mathrm{Cl}^{-}$currents showed considerable variability and was not statistically

Fig. 1. DIDS inhibits a voltage-dependent potassium selective current and the swelling-activated chloride current. A, top, original current recordings obtained from HEK 293 Phoenix cells in whole-cell configuration with pipette solution 2 and bath solution 3 before and after the addition of $1 \mathrm{mM}$ DIDS or the vehicle to the bath solution; bottom, current (pA) to voltage $(\mathrm{mV})$ relationship of $\mathrm{K}+$ currents before, immediately after ( $0 \mathrm{~min}$ ) and $5 \mathrm{~min}$ after the addition of DIDS or the vehicle to the bath solution. $\mathrm{B}$, top, original current recordings obtained from HEK 293 Phoenix cells in whole-cell configuration with pipette solution 1 and isotonic bath solution 1, hypotonic bath solution 2 and after the addition of $1 \mathrm{mM}$ DIDS or the vehicle to the hypotonic bath solution; bottom, current $(\mathrm{pA})$ to voltage $(\mathrm{mV})$ relationship of $\mathrm{Cl}$ - currents in isotonic bath solution 1 , hypotonic bath solution 2 at the maximal current activation (or steady state, hypo SS), immediately after (0 $\mathrm{min})$ and $5 \mathrm{~min}$ after the addition of DIDS or the vehicle to the hypotonic bath solution. Scale of original current recordings of panel B (inset) also applies to A. Numbering of solutions refers to Table 1 . (n) indicates the number of cells. ${ }^{*}$ : $\mathrm{p}<0.05,{ }^{* *}$ : $\mathrm{p}<0.01,{ }^{* * *}$ : $\mathrm{p}<0.001$, before and 5 min after addition of DIDS or the vehicle to the bath solution, two-tailed paired Student's t test.

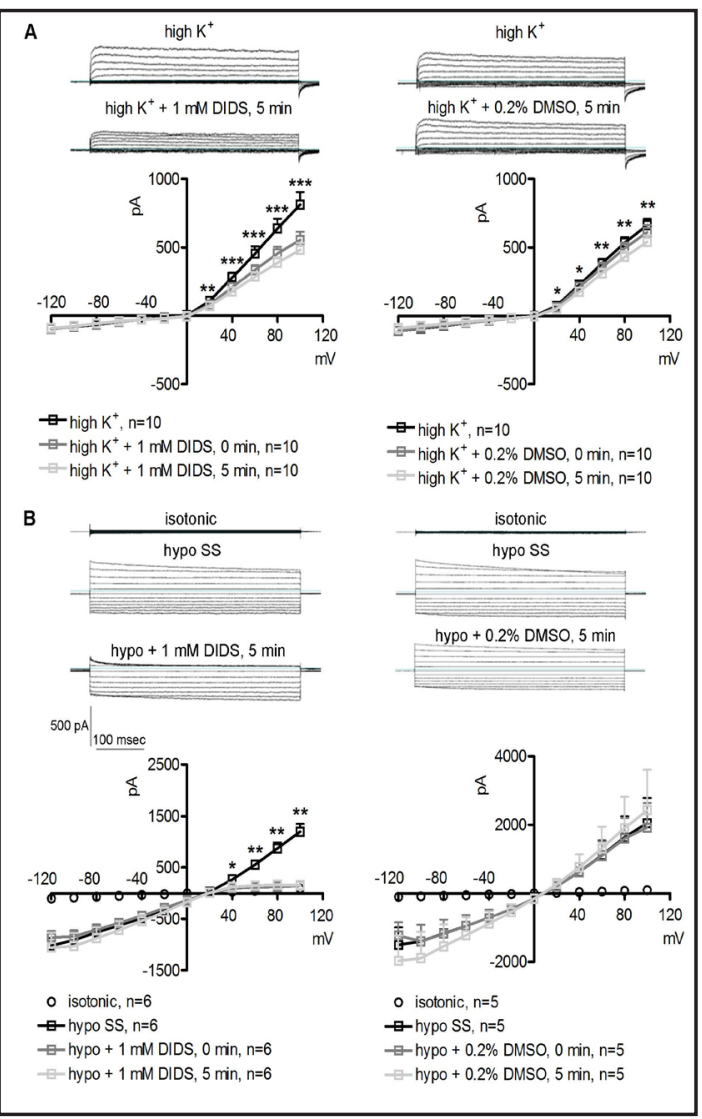




\section{Cellular Physiology Cell Physiol Biochem 2018;45:867-882 \begin{tabular}{l|l|l|l} 
DOI: 10.1159/000487282 & O 2018 The Author(s). Published by S. Karger AG, Basel \\
www.karger.com/cpb
\end{tabular} \\ Costa et al.: Kv 3.1 and Chloride Channel Blockers}

Fig. 2. NPPB inhibits a voltage-dependent potassium selective current and the swelling-activated chloride current. A, top, original current recordings obtained from HEK 293 Phoenix cells in whole-cell configuration with pipette solution 2 and bath solution 3 before and after the addition of $1 \mathrm{mM}$ NPPB or the vehicle to the bath solution; bottom, current $(\mathrm{pA})$ to voltage $(\mathrm{mV})$ relationship of $\mathrm{K}+$ currents before, immediately after ( $0 \mathrm{~min}$ ) and $5 \mathrm{~min}$ after the addition of NPPB or the vehicle to the bath solution. $B$, top, original current recordings obtained from HEK 293 Phoenix cells in whole-cell configuration with pipette solution 1 and isotonic bath solution 1 , hypotonic bath solution 2 and after the addition of $1 \mathrm{mM} \mathrm{NPPB}$ or the vehicle to the hypotonic bath solution; bottom, current $(\mathrm{pA})$ to voltage $(\mathrm{mV})$ relationship of Cl- currents in isotonic bath solution 1 , hypotonic bath solution 2 at the maximal current activation (or steady state, hypo SS), immediately after ( $0 \mathrm{~min}$ ) and $5 \mathrm{~min}$ after the addition of NPPB or the vehicle to the hypotonic bath solution. Scale of original current recordings of panel B (inset) also applies to A. Numbering of solutions refers to Table 1 . (n) indicates the number of cells. *: $\mathrm{p}<0.05,{ }^{* *}: \mathrm{p}<0.01$, before and 5 min after addition of NPPB or the vehicle to the bath solution, two-tailed paired Student's t test.

Fig. 3. Niflumic acid inhibits a voltage-dependent potassium selective current and the swelling-activated chloride current. A, top, original current recordings obtained from HEK 293 Phoenix cells in whole-cell configuration with pipette solution 2 and bath solution 3 before and after the addition of $1 \mathrm{mM}$ niflumic acid or the vehicle to the bath solution; bottom, current $(\mathrm{pA})$ to voltage $(\mathrm{mV})$ relationship of $\mathrm{K}+$ currents before, immediately after ( $0 \mathrm{~min}$ ) and $5 \mathrm{~min}$ after the addition of niflumic acid or the vehicle to the bath solution. B, top, original current recordings obtained from HEK 293 Phoenix cells in whole-cell configuration with pipette solution 1 and isotonic bath solution 1 , hypotonic bath solution 2 and after the addition of $1 \mathrm{mM}$ niflumic acid or the vehicle to the hypotonic bath solution; bottom, current $(\mathrm{pA})$ to voltage $(\mathrm{mV})$ relationship of $\mathrm{Cl}$ - currents in isotonic bath solution 1 , hypotonic bath solution 2 at the maximal current activation (or steady state, hypo SS), immediately after ( $0 \mathrm{~min}$ ) and $5 \mathrm{~min}$ after the addition of niflumic acid or the vehicle to the hypotonic bath solution. Scale of original current recordings of panel B (inset) also applies to A. Numbering of solutions refers to Table 1. (n) indicates the number of cells. *: $\mathrm{p}<0.05$, $* *$ : $<<0.01$, before and 5 min after addition of niflumic acid or the vehicle to the bath solution, two-tailed paired Student's t test.
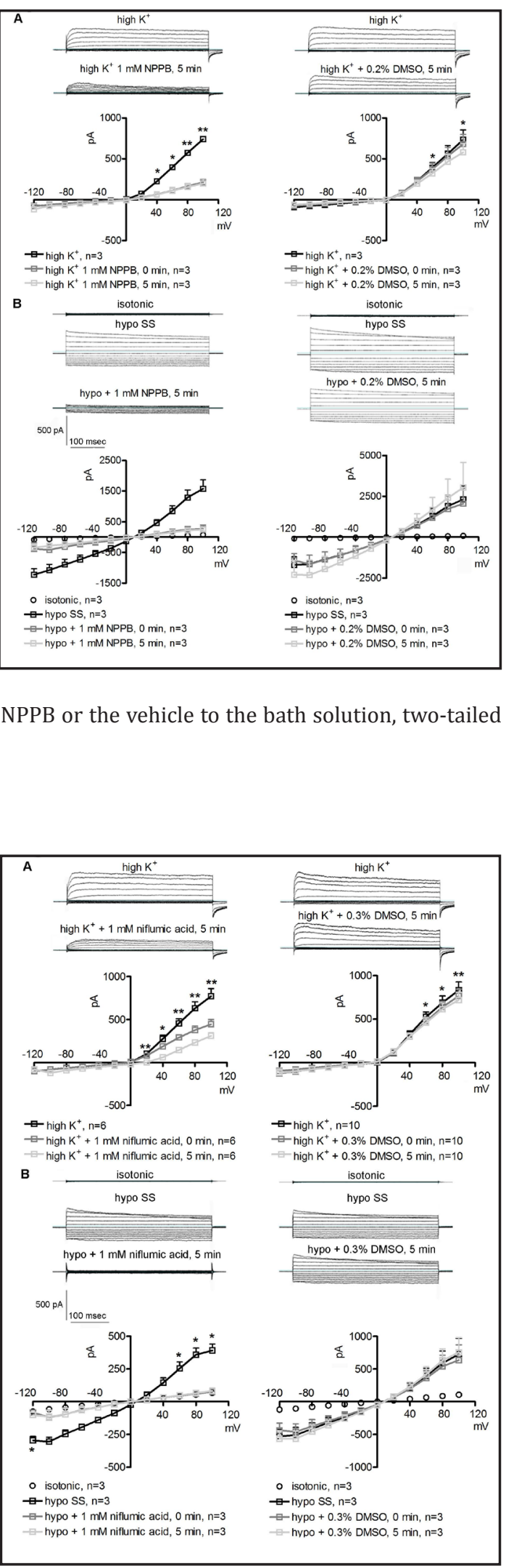

KARGER 
significant (Table 2). The inhibition of $\mathrm{K}^{+}$currents determined immediately after exposure of cells to $0.001 \mathrm{mM}$ DIDS was $\sim 8.2 \%$ and $\sim 11.0 \%$ after 5 minutes (Table 2). These values refer to the peak current and are corrected for the mean $\%$ of current variation observed in control cells. In addition, the analysis of $\tau$ values revealed a significant acceleration of current inactivation in time (Table 2). The effect on peak current as well as on current inactivation become more pronounced with $0.01 \mathrm{mM}$ DIDS. The increasing inhibition of the peak current observed with DIDS concentrations higher than $0.01 \mathrm{mM}(>20 \%$ with $1 \mathrm{mM}$ DIDS, Table 2, Fig. 1A and [28] masked the effect on the current inactivation (Table 2).

In the range tested $(0.0001-1 \mathrm{mM})$, the lowest concentration of DIDS with a statistically significant inhibitory effect on $\mathrm{Cl}^{-}$currents was $0.01 \quad \mathrm{mM} \quad(\sim 28 \%$ and $\sim 29 \%$ immediately after and 5 minutes after exposure of cells to DIDS, respectively; Table 2). DIDS concentrations of 0.1-1 mM exhibited a significantly higher inhibitory effect on $\mathrm{Cl}^{-}$currents compared to $\mathrm{K}^{+}$currents (Table 2 and Fig. 1B), that was typically voltagedependent, i.e. more pronounced on the outward currents, in agreement with previous observations [1]. Also the current inactivation in time was significantly accelerated (Table 2).

In the range tested $(0.001-1 \mathrm{mM})$, the lowest concentration of NPPB with a statistically significant inhibitory effect was $0.01 \mathrm{mM}$. This was observed on both $\mathrm{Cl}^{-}$and $\mathrm{K}^{+}$currents. The inhibition of $\mathrm{K}^{+}$currents determined immediately after exposure of cells to $0.01 \mathrm{mM}$ NPPB was $\sim 7 \%$ and $\sim 18 \%$ after 5 minutes (Table 2 ) and did not significantly differ from that observed on $\mathrm{Cl}^{-}$currents (i.e. $\sim 13 \%$ and $\sim 37 \%$, respectively; Table 2). Prolonged exposure (5 minutes) to 0.1-1 mM NPPB led to a significantly higher inhibitory effect on $\mathrm{Cl}^{-}$currents compared to $\mathrm{K}^{+}$currents (Fig. 2 and Table 2).

Table 2. Current variation (in \%) and time constant of current inactivation ( $\tau$, in msec) determined in HEK 293 Phoenix cells immediately after ( $0 \mathrm{~min}$ ) and 5 minutes after exposure to the indicated inhibitors or their vehicles. The $\%$ of current variation was calculated at $+100 \mathrm{mV}$ between peak currents recorded before and immediately after ( $0 \mathrm{~min})$, as well as before and 5 minutes after exposure of cells to the inhibitor, and was corrected for the average of the corresponding current variation observed in cells treated with the vehicle. (-) indicates a current decrease, $(+)$ indicates a current increase. Being $0.001 \mathrm{mM}$ niflumic acid ineffective on the $\mathrm{K}^{+}$current, a lower concentration $(0.0001 \mathrm{mM})$ was only assayed on the $\mathrm{Cl}^{-}$current. *: $\mathrm{p}<0.05$, **: $\mathrm{p}<0.01,{ }^{* * *}$ : $\mathrm{p}<0.001$, n.s.: not significant compared to the vehicle, two-tailed, unpaired Student's t test. $\S: \mathrm{p}<0.05, \S \S: \mathrm{p}<0.01, \S \S \S: \mathrm{p}<0.001$ compared to the $\mathrm{K}^{+}$ current, two-way ANOVA with Bonferroni's ad-hoc post-test

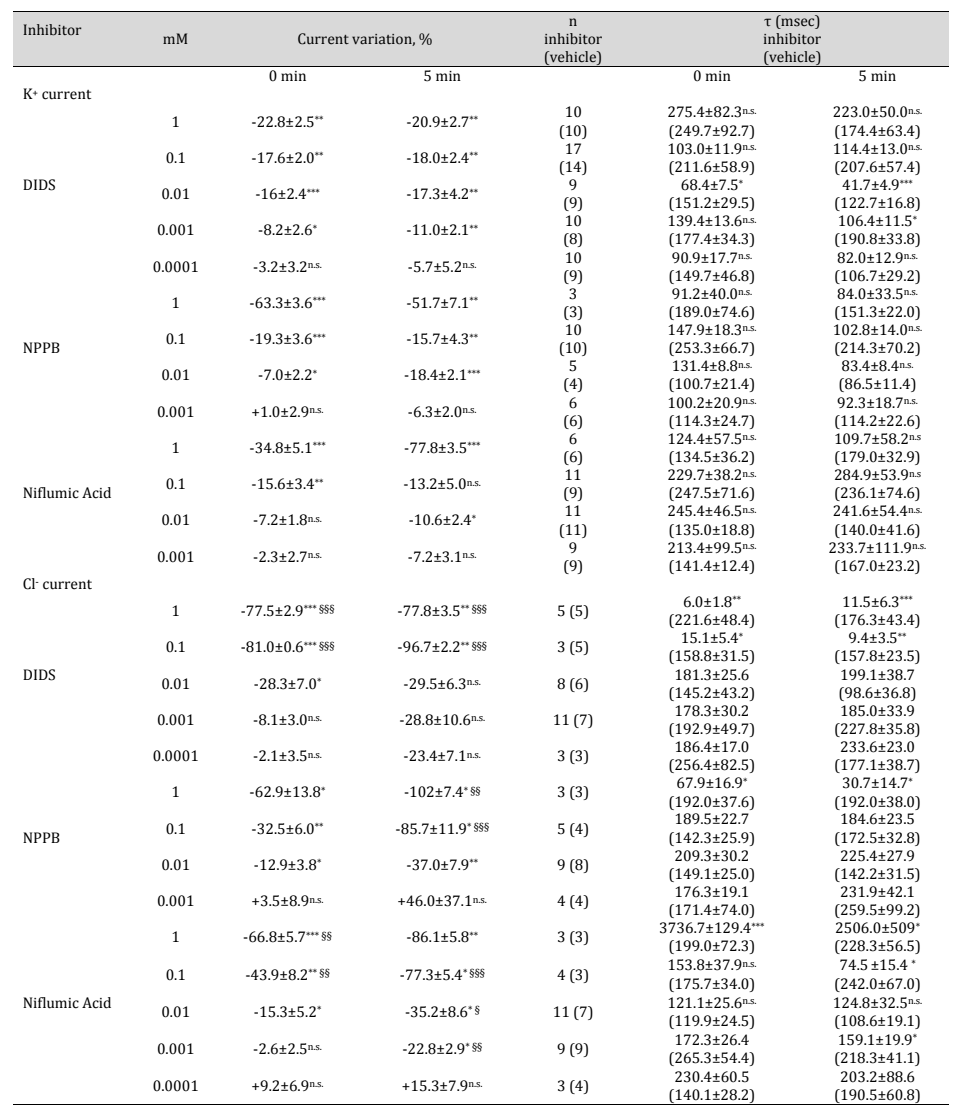


Fig. 4. Kv 3.1 is expressed in HEK 293/HEK 293 Phoenix cells and generates the voltage-dependent outwardly rectifying potassium selective current. A, total RNA was extracted from HEK 293 Phoenix cells, reverse transcribed and subjected to PCR amplification with primers specific for the indicated $\alpha$ subunits of $\mathrm{Kv}$ channels. The transcript of the housekeeping gene $\beta$-actin was amplified as a control. The image is representative of three independent replicates leading to a same result. B, top: the levels the transcripts of $\mathrm{Kv} 3.1$ and $\beta$-actin were detected by RT-PCR in 3 independent samples of total RNA from HEK 293 Phoenix cells transfected for 72 hours with 360 pmol of Kv 3.1 siRNA or control siRNA. To exclude genomic DNA contamination, the PCR reaction was also conducted on samples of total RNA not subjected to the reverse transcription reaction (-RT);

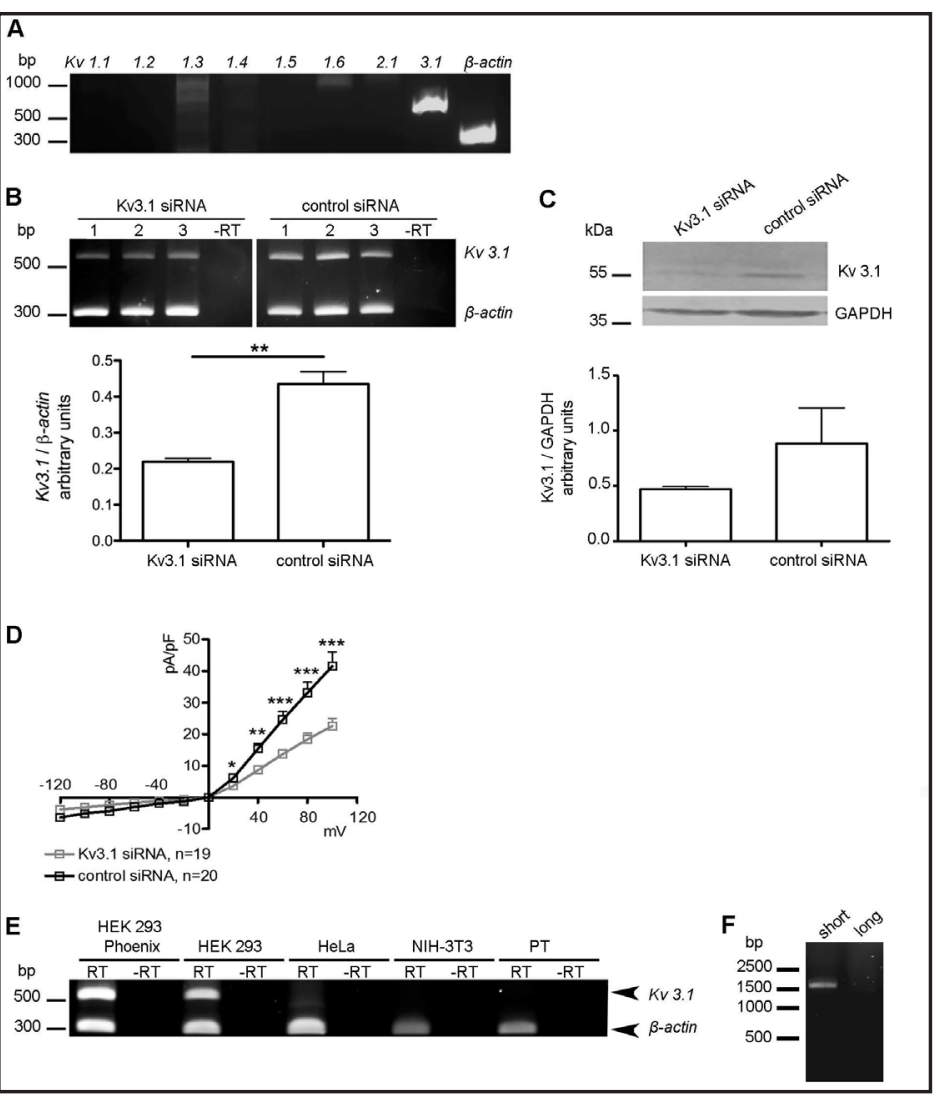
bottom: densitometric analysis of

the Kv 3.1 signal normalized to the $\beta$-actin signal; **: $\mathrm{p}<0.01$, two-tailed, unpaired Student's t-test. C, top: the levels the Kv 3.1 and GAPDH proteins were detected by Western blot in 3 independent samples of total protein extracts from HEK 293 Phoenix cells transfected for 72 hours with 360 pmol of Kv 3.1 siRNA or control siRNA; bottom: densitometric analysis of the Kv 3.1 signal normalized to the GAPDH signal. D, the magnitude of $\mathrm{K}+$ currents was monitored by whole cell patch-clamp in HEK 293 Phoenix cells transfected with Kv 3.1 siRNA or control siRNA. The current density $(\mathrm{pA} / \mathrm{pF})$ to voltage $(\mathrm{mV})$ relationship is shown. (n) indicated the number of cells. ***: p<0.001, **: p<0.01, *: p<0.05, two-tailed, unpaired Student's t-test. E, total RNA was extracted from the indicated cell lines, reverse transcribed and subjected to PCR amplification with primers specific for transcripts encoding the $\alpha$ subunit of $\mathrm{Kv} 3.1$ channel. $\beta$-actin transcript was amplified as an internal control. -RT as in B. The image is representative of three independent replicates leading to a same result. PT, kidney proximal tubule cells in primary culture. F, total RNA was extracted from HEK 293 Phoenix cells, reverse transcribed and subjected to PCR amplification with primers specific either for the short (NM_004976.4) or long (NM_001112741.1) transcripts of Kv 3.1.

In the range tested $(0.0001-1 \mathrm{mM})$, the lowest concentration of niflumic acid with a statistically significant inhibitory effect was $0.001 \mathrm{mM}$. This was observed on $\mathrm{Cl}^{-}$but not on $\mathrm{K}^{+}$currents. The inhibition of $\mathrm{Cl}^{-}$currents determined immediately after exposure of cells to $0.001 \mathrm{mM}$ niflumic acid was $\sim 2.6 \%$ and $\sim 23 \%$ after 5 minutes (Table 2). The last value was significantly different from that observed on $\mathrm{K}^{+}$currents (i.e. $\sim 7 \%$, Table 2). Increasing concentrations (0.01-1 mM) of niflumic acid inhibited both $\mathrm{Cl}^{-}$and $\mathrm{K}^{+}$currents; the effect on $\mathrm{Cl}^{-}$currents was statistically higher, with the exception of $1 \mathrm{mM}$ niflumic acid (5 minutes exposure), which inhibited $\mathrm{Cl}^{-}$and $\mathrm{K}^{+}$currents to a same extent ( $\sim 80 \%$, Fig. 3 and Table 2$)$.

\section{Molecular identity of the potassium selective current}

To identify the channel(s) underlying the voltage-dependent $\mathrm{K}^{+}$current, end-point PCR was performed on cDNA from total mRNA of HEK 293 Phoenix cells with primers pairs specific 


\section{Cellular Physiology Cell Physiol Biochem 2018;45:867-882 and Biochemistry \begin{tabular}{c|c|c|c|} 
DOI: 10.1159/000487282 & O 2018 The Author(s). Published by S. Karger AG, Basel \\
Published
\end{tabular}

Fig. 5. Kv 3.1 currents are sensitive to niflumic acid. A, original current recordings obtained from untransfected (mock) or Kv 3.1-transfected (+100 mV) NIH-3T3 cells in whole-cell configuration with pipette solution 2 and bath solution 3 before and $5 \mathrm{~min}$ after the addition of $0.1 \mathrm{mM}$ niflumic acid or the vehicle $(0.03 \%$ DMSO) to the bath solution. The current recording obtained in the presence of niflumic acid is indicated by a black arrowhead. B, Intensity (pA) and C, time constant of inactivation $(\tau)$ of current measured at $+100 \mathrm{mV}$ in cells expressing Kv 3.1 before (pre), immediately after ( $0 \mathrm{~min})$ and $5 \mathrm{~min}$ after exposure to $0.1 \mathrm{mM}$ niflumic acid or the vehicle. Numbering of solutions refers to Table 1. (n) indicates the number of cells. *: p<0.05, **: p<0.01, before and 5 min after addition of niflumic acid to the bath solution, two-tailed paired Student's t test.

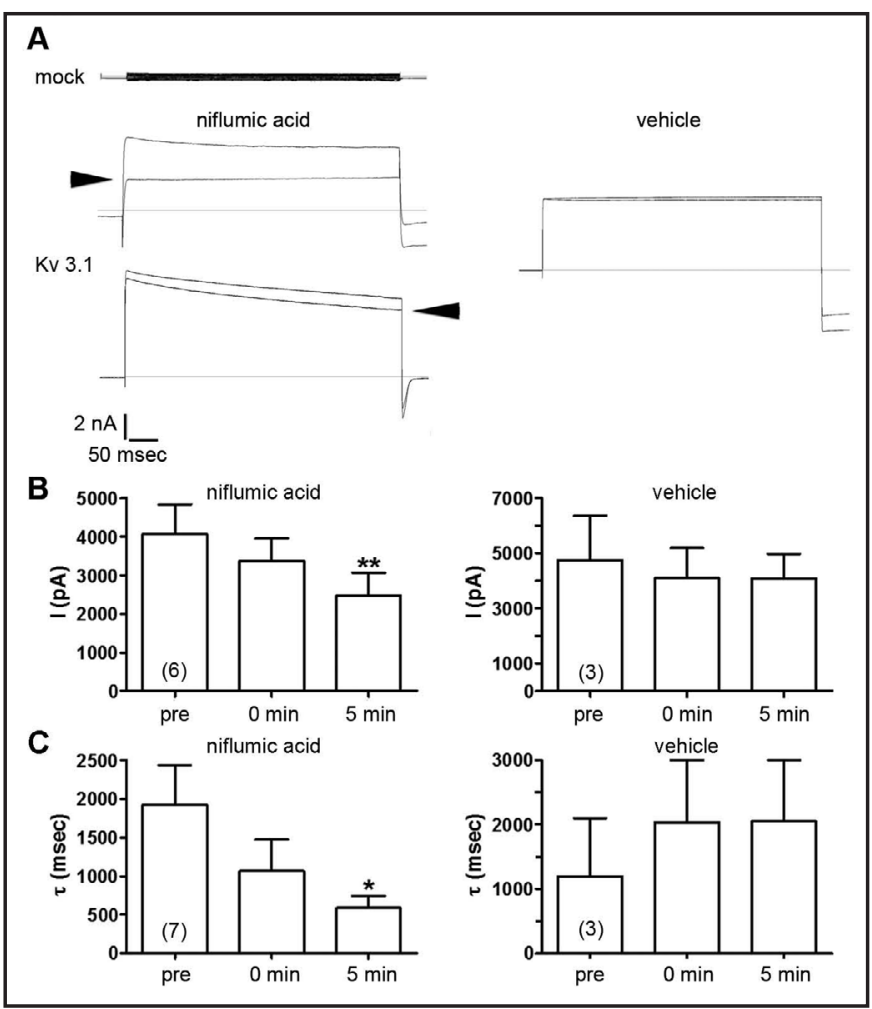

for different members of the Kv family (Kv 1.1, Kv 1.2, Kv 1.3, Kv 1.4, Kv 1.5, Kv 1.6, Kv 2.1 and Kv 3.1). Of these, only Kv 3.1 was reproducibly detected in three independent cDNA samples (Fig. 4A), and the identity of the amplicon was confirmed by Sanger sequencing. A band with size compatible with the Kv 1.3 amplicon was detected in two out of six independent cDNA samples from of HEK 293 Phoenix cells, however, Sanger sequencing could not confirm the identity of this PCR product. All the remaining primer couples did not amplify a band of the expected size, also following variation of the annealing temperature between 47 and $61{ }^{\circ} \mathrm{C}$.

To assess if the channel Kv 3.1 is involved in determining the voltage-dependent $\mathrm{K}^{+}$ current in HEK 293 Phoenix cells, the expression of Kv 3.1 mRNA was silenced by RNA interference. Three different siRNAs (180-360 pmol) were assayed following a 48-72 $\mathrm{h}$ transfection in cells. A $72 \mathrm{~h}$ transfection with 360 pmol of equimolar amounts of siRNA \#1 and 2 led to the best result, i.e. a Kv 3.1 mRNA silencing of $\sim 49 \%$ (Fig. 4B), which corresponded to a Kv 3.1 protein silencing of $\sim 47 \%$, (Fig. $4 \mathrm{C}$ ) and was utilized for functional testing. In these conditions, the voltage-dependent $\mathrm{K}^{+}$current in HEK 293 Phoenix cells was reduced by $\sim 45 \%$ (Fig. 4D), strongly suggesting that Kv 3.1 is the underlying channel. $\mathrm{Kv} 3.1$ was also detected in cDNA samples from HEK 293 cells, but not in NIH-3T3, HeLa or mouse primary proximal tubules cells (Fig. 4E). The weak band detected in HeLa cells is lower than the expected size and is most likely an unspecific PCR product (Fig. 4E). Of the two known Kv 3.1 transcripts, only the short transcript was detected in HEK 293 Phoenix cells (Fig. 4F).

To further confirm the molecular identity of the channel eliciting the voltage-dependent $\mathrm{K}^{+}$-selective current in HEK 293/293 Phoenix cells, the short isoform of Kv 3.1 was expressed in a heterologous system, and the biophysical and pharmacological properties of the resulting current were studied and compared to those of the endogenous current measured in HEK 293/293 Phoenix cells. For this, a cell type void of macroscopic endogenous voltagedependent $\mathrm{K}^{+}$-selective current, i.e. NIH-3T3 cells, was chosen. NIH-3T3 cells transiently transfected with a plasmid vector (pcDNA3.1+P2A-eGFP; see Methods for further details) encoding the short isoform of Kv 3.1 and voltage-clamped with intracellular and extracellular solutions suitable for isolating $\mathrm{K}^{+}$currents (Table 1) exhibited a large current which was never observed in mock transfected cells (Fig. 5A). This current is therefore the consequence 


\section{Cellular Physiology Cell Physiol Biochem 2018;45:867-882 \\ \begin{tabular}{ll|l} 
and Biochemistry Published online: February 08, 2018 & $\begin{array}{l}\text { (c) } 2018 \text { The Author(s). Published by S. Karger AG, Basel } \\
\text { www.karger.com/cpb }\end{array}$ \\
\hline
\end{tabular} \\ Costa et al.: Kv 3.1 and Chloride Channel Blockers}

of the activity of heterologous $\mathrm{Kv} 3.1$. The biophysical fingerprints of this current were reminiscent of those of the endogenous $\mathrm{K}^{+}$current measured in HEK 293/293 Phoenix cells, i.e., voltage-dependent activation at depolarizing potentials, rapid activation kinetic and slow time-dependent inactivation at holding potentials above $+40 \mathrm{mV}$ (Fig. $5 \mathrm{~A}$ ). Exposure of cells to $0.1 \mathrm{mM}$ niflumic acid either led to an inhibition of peak current ( $\sim 17 \%$ and $\sim 39 \%$ immediately after and 5 minutes after exposure to niflumic acid, respectively, Fig. 5B) or significantly accelerated the inactivation of the current in time (Fig. 5C). These effects were not observed following exposure of cells to the vehicle (Figs. 5B and C). These results show that Kv 3.1 is sensitive to niflumic acid and further support the concept that Kv 3.1 sustains the voltage-dependent $\mathrm{K}^{+}$-selective current in HEK 293/293 Phoenix cells.

\section{Discussion}

Voltage-gated (Kv), outwardly rectifying $\mathrm{K}^{+}$currents of several hundreds of picoamperes detectable with the whole-cell configuration of patch-clamp were reported in human embryonic kidney (HEK 293) [29-32] and HEK 293-derived cell lines ([21, 26] and Figs. $1 \mathrm{~A}, 2 \mathrm{~A}$ and $3 \mathrm{~A}$ ), and were previously characterized in detail. Shortly, these currents have an activation potential around $-20 \mathrm{mV}$, show a rapid activation kinetic and slow time-dependent inactivation at holding potentials above $+40 \mathrm{mV}$, are blocked by tetraethyl ammonium (TEA) and $\mathrm{Cs}^{+}$and are highly selective for $\mathrm{K}^{+}[21]$. These currents are active in an isotonic medium (Fig. 1A, 2A and 3A, high $\mathrm{K}^{+}$) and exhibit a partial and slow spontaneous rundown in time after establishing the whole cell configuration and maintaining a holding potential of $-60 \mathrm{mV}$ $(11.5 \%$ at $+100 \mathrm{mV}$ in 5 minutes, Fig. $1 \mathrm{~A})$. Exposure to a hypotonic extracellular medium does not further activate these currents but appears to slow their rundown [26].

The chloride currents elicited in HEK 293 Phoenix cells following exposure to an extracellular hypotonic medium (Figs. 1B, 2B and 3B) reproduce the biophysical properties of the swelling-activated chloride current ICl,swell, including outward rectification and slow time-dependent inactivation at holding potentials higher than $+40 \mathrm{mV}[22,24-26]$.

Messenger RNA of both the delayed rectifier $\left(\mathrm{I}_{\mathrm{K}}\right)$ and transient $\left(\mathrm{I}_{\mathrm{A}}\right)$ outward Kv channel family members were detected in HEK 293 cells $[31,32]$. However, the fast activation and little to no inactivation kinetics suggest that delayed rectifier $\left(\mathrm{I}_{\mathrm{K}}\right)$ channels may be primarily implicated in generating this current. Accordingly, abundant Kv 3.1 mRNA was found in HEK 293 Phoenix cells (Fig. 4A). Interestingly, the same mRNA was found in HEK 293 cells, which possess the voltage-gated $\mathrm{K}^{+}$current, but not in HeLa, NIH-3T3 or primary proximal tubule cell cultures (Fig. 4E), where the voltage-gated $\mathrm{K}^{+}$current was not detected. Primary proximal tubule, HeLa and NIH-3T3 cells were used as models of epithelial cells of kidney origin, extra-renal epithelial cells and non-epithelial cells, respectively. Therefore, the voltagegated, outwardly rectifying $\mathrm{K}^{+}$current detectable in HEK 293 and HEK 293 Phoenix does not represent a common feature of cells of kidney or epithelial derivation, bur rather seems to be characteristic of HEK 293 and HEK 293 Phoenix. The presence of Kv 3.1 protein in HEK 293 Phoenix cells was confirmed by Western blot (Fig. 4C), and Kv 3.1 mRNA silencing (Fig. 4B) was accompanied by a significant $(\sim 45 \%)$ decrease of the voltage-gated $\mathrm{K}^{+}$current (Fig. 4D). Based on these evidences, it is reasonable to assume that Kv 3.1 is the main molecular entity underlying the voltage-gated $\mathrm{K}^{+}$current in HEK 293/HEK 293 Phoenix cells, although a minor contribution of other $\mathrm{Kv}$ family members cannot be ruled out.

The human voltage-gated $\mathrm{K}^{+}$channel Kv 3.1 gene encodes a protein (KCNC1) resembling the Drosophila Shaw subfamily channel type, and is predominantly - although not exclusively expressed in excitable cells [16], where it regulates neuronal excitability [33], neural precursor cell proliferation and differentiation [34] as well as muscle contraction [35], amongst others. Specifically in neurons, the Kv 3.1 biophysical properties (i.e., the positively shifted voltage dependency and very fast deactivation rate after membrane repolarization) can enable fast repolarization of action potentials without compromising action potential initiation and are therefore essential for proper activity of neurons characterized by repetitive firing at high 


\section{Cellular Physiology Cell Physiol Biochem 2018;45:867-882 \begin{tabular}{ll|l} 
and Biochemistry Published online: February 08, 2018 & $\begin{array}{l}\text { (c) } 2018 \text { The Author(s). Published by S. Karger AG, Basel } \\
\text { www.karger.com/cpb }\end{array}$ \\
\hline
\end{tabular} \\ Costa et al.: Kv 3.1 and Chloride Channel Blockers}

frequency, such as auditory [36] and fast-spiking inhibitory GABAergic interneurons in the mammalian cortex [37-39]. Also, Kv 3.1 is involved in regulating the duration and amplitude of the presynaptic potential, thus controlling evoked neurotransmitter release [40]. Given their essential role in modulating neuronal activity, reduction of Kv 3.1 channel expression and/or activity has been linked to neurodegenerative disorders such as Alzheimer's disease [41], inherited ataxia [42, 43], schizophrenia [44] and intellectual disability [45]. Recently, a role of Kv 3.1 in causing a distinct form of progressive myoclonus epilepsy called myoclonus epilepsy and ataxia due to potassium channel mutation (MEAK) has been described [46]. Specifically, loss of Kv 3.1 function in inhibitory GABAergic interneurons and cerebellar neurons due to genetic mutation was found to lead to myoclonus and seizures accompanied by ataxia and tremor [46-48]. Positive modulators of Kv 3.1 channels are envisioned as potential therapeutic agents in the treatment of epilepsy, hearing disorders, schizophrenia and cognitive impairments [49].

Besides neurons and skeletal muscle, Kv 3.1 channels are also expressed in various other tissues and cells including B lymphocytes [50], germ cells, lung and testis [16], but not in cell of renal derivation, such as renal inner medullary collecting duct [51], BHK21 [52] or proximal tubule cells (Fig. 4E). This observation points to the fact that HEK 293/293 Phoenix cells possess peculiar properties with respect to other cells of epithelial origin, express channel proteins normally found in excitable cells and, due to the presence of large endogenous Kv currents, are not ideal for the characterization of heterologous Kv channels. However, these cells are readily available, easy to cultivate, guarantee a relatively high throughput when employed for patch clamp and can be used to test the pharmacological properties of molecules targeting Kv 3.1 channels. As previously mentioned, Kv 3.1 is activated upon depolarization in neurons and participates in the re-polarization of membrane potential. In HEK 293/293 Phoenix cells, most likely the membrane potential never reaches values allowing for the activation of Kv 3.1 channel. Therefore, the physiological role of Kv $3.1 \mathrm{in}$ these cells remains undetermined.

The gene encoding $\mathrm{Kv} 3.1$ (NG_041827.1) gives rise to two different transcripts (NM_001112741.1 and NM_004976.4) by alternative splicing. These transcripts encode two distinct $\mathrm{Kv} 3.1$ protein isoforms that differ at their C-termini: a longer isoform (NP_001106212.1, designated in the literature as "isoform 1", "b" or "alpha"), and shorter isoform (NP_004967.1, called "isoform 2", "a" or "beta"). Kv 3.1 alpha was the predominant splice variant found in neurons of the adult brain, whereas Kv 3.1 beta appeared to be the predominant species in embryonic and perinatal neurons, at least in rat. Kv 3.1 beta mRNA was also detected in the adult rat brain, although at a lower levels compared to Kv 3.1 alpha [53]. Both isoforms appear to be functional [54]. Accordingly, in HEK 293/293 Phoenix cells, which originated from embryonic tissue, only the transcript encoding the shorter isoform (Kv 3.1 beta) was detected (Fig. 4F), while only the transcript encoding the longer isoform (Kv 3.1 alpha) was detected in human adult brain (data not shown).

Given the importance of Kv 3.1 channels in human physiology and pathology, a complete understanding of their pharmacological properties is mandatory. Notably, Kv 3.1 current is sensitive to both 4-aminopyridine (IC50 $=29 \mu \mathrm{M}$ ) and TEA (IC50 $=0.2 \mathrm{mM}$ ) [16]. Here, it is shown that the chloride transport inhibitor DIDS leads to alteration of Kv 3.1 current properties, as demonstrated by acceleration of the current inactivation kinetics, minor, but significant peak current inhibition at $1 \mu \mathrm{M}$ and a sizeable $(>20 \%)$ peak current inhibition at $1 \mathrm{mM}$ (Table 2). The effect of DIDS appeared to be significantly more pronounced on $\mathrm{Cl}^{-}$ rather than $\mathrm{K}^{+}$currents only at concentrations $\geq 0.1 \mathrm{mM}$ (Table 2 and Fig. 1). Similarly, 0.01$1 \mathrm{mM}$ of the chloride channel blocker NPPB led to a significant inhibition of both peak $\mathrm{K}^{+}$ and $\mathrm{Cl}^{-}$currents (Fig. 2 and Table 2). The effect of NPPB appeared to be significantly more pronounced on $\mathrm{Cl}^{-}$than $\mathrm{K}^{+}$currents only at concentrations $\geq 0.1 \mathrm{mM}$ and after prolonged ( 5 minutes) exposure (Table 2).

Niflumic acid (https://www.drugbank.ca/drugs/DB04552, accessed on the $5^{\text {th }}$ of September 2017) is a member of the fenamate class of nonsteroidal anti-inflammatory drugs and was originally developed for the treatment of rheumatic disorders [55]. This drug and 


\section{Cellular Physiology Cell Physiol Biochem 2018;45:867-882 \begin{tabular}{l|l|l|l} 
DOI: 10.1159/000487282 & $\begin{array}{l}\text { O } 2018 \text { The Author(s). Published by S. Karger AG, Basel } \\
\text { www.karger.com/cpb }\end{array}$
\end{tabular}

its derivatives are widely used in clinics for the relief of chronic and acute pain conditions [56]. Niflumic acid is also known as an inhibitor of several anion channels, including $\mathrm{Ca}^{++}$activated [57-59] and swelling-activated [12] $\mathrm{Cl}^{-}$channels, and was reported to variably affect different membrane ion transport systems, such as anion exchangers $[28,60]$, the glycine [61], GABA(A) [62] and N-methyl-D-aspartate [63] receptors and T-type calcium channels [64]. The findings presented here show that 0.01-1 $\mathrm{mM}$ niflumic acid, despite being more potent on the swelling-activated $\mathrm{Cl}^{-}$current, also significantly blocked the $\mathrm{K}^{+}$current (Table 2 and Fig. 3). The plasma concentration of niflumic acid after administration of a single oral therapeutic dose of $750 \mathrm{mg}$ talniflumate to healthy human volunteers approximates values of $4000-7000 \mathrm{ng} / \mathrm{ml}$ (i.e. $14-25 \mu \mathrm{M})[65,66]$, thus falling within the concentration range capable of affecting the activity of Kv 3.1 channels. Therefore, the use of niflumic acid and its prodrugs in the treatment of inflammatory conditions in patients with concurrent pathologies linked to Kv 3.1 dysfunction may result contraindicated.

To our knowledge, this is the first report of an effect of chloride channel blockers on Kv 3.1 currents. The findings presented here indicate that sensitivity of a physiological phenomenon to either NPPB, DIDS or niflumic acid does not necessarily imply an involvement of $\mathrm{Cl}^{-}$transport but can also be explained by an inhibition of voltage-dependent $\mathrm{K}^{+}$currents, and possibly of the Kv 3.1 channel.

\section{Acknowledgements}

The authors gratefully acknowledge the expert secretarial assistance of Elisabeth Mooslechner.

E. Bernardinelli is supported by the PMU-FFF fund E-17/25/128-BER.

\section{Disclosure Statement}

The authors declare that they have no conflicts of interest.

\section{References}

1 Hume JR, Duan D, Collier ML, Yamazaki J, Horowitz B: Anion transport in heart. Physiol Rev 2000;80:31-81.

-2 Zhou SS, Yang J, Li YQ, Zhao LY, Xu M, Ding YF: Effect of $\mathrm{Cl}^{-}$channel blockers on aconitine-induced arrhythmias in rat heart. Exp Physiol 2005;90:865-872.

-3 Hogg RC, Wang Q Large WA: Effects of $\mathrm{Cl}^{-}$channel blockers on $\mathrm{Ca}^{++}$-activated chloride and potassium currents in smooth muscle cells from rabbit portal vein. Br J Pharmacol 1994;111:1333-1341.

-4 Illek B, Fischer H, Kreusel KM, Hegel U, Clauss W: Volume-sensitive basolateral K channels in HT-29/B6 cells: Block by lidocaine, quinidine, NPPB, and Ba²+. Am J Physiol 1992;263:C674-683.

5 Zhou SS, Gao Z, Dong L, Ding YF, Zhang XD, Wang YM, Pei JM, Gao F, Ma XL: Anion channels influence ECC by modulating L-type Ca(2+) channel in ventricular myocytes. J Appl Physiol (1985) 2002;93:1660-1668.

6 Popp R, Englert HC, Lang HJ, Gogelein H: Inhibitors of nonselective cation channels in cells of the bloodbrain barrier. EXS 1993;66:213-218.

7 Lang F: Mechanisms and significance of cell volume regulation. J Am Coll Nutr 2007;26:613S-623S.

-8 Lefevre T, Lefevre IA, Coulombe A, Coraboeuf E: Effects of chloride ion substitutes and chloride channel blockers on the transient outward current in rat ventricular myocytes. Biochim Biophys Acta 1996;1273:31-43.

-9 Wang HS, Dixon JE, McKinnon D: Unexpected and differential effects of $\mathrm{Cl}^{-}$channel blockers on the Kv4.3 and Kv4.2 $\mathrm{K}^{+}$channels. Implications for the study of the I(to2) current. Circ Res 1997;81:711-718.

10 Dick GM, Kong ID, Sanders KM: Effects of anion channel antagonists in canine colonic myocytes: Comparative pharmacology of $\mathrm{Cl}^{-}, \mathrm{Ca}^{2+}$ and $\mathrm{K}^{+}$currents. Br J Pharmacol 1999;127:1819-1831. 


\section{Cellular Physiology Cell Physiol Biochem 2018;45:867-882 \begin{tabular}{ll|l|l|l} 
DOI: 10.1159/000487282 & 2018 The Author(s). Published by S. Karger AG, Basel \\
and Biochemistry & Published online: February 08, 2018 www.kom/cpb
\end{tabular} \\ Costa et al.: Kv 3.1 and Chloride Channel Blockers}

11 Zhou SS, Zhang LB, Sun WP, Xiao FC, Zhou YM, Li YJ, Li DL: Effects of monocarboxylic acid-derived Cl channel blockers on depolarization-activated potassium currents in rat ventricular myocytes. Exp Physiol 2007;92:549-559.

-12 Furst J, Gschwentner M, Ritter M, Botta G, Jakab M, Mayer M, Garavaglia L, Bazzini C, Rodighiero S, Meyer G, Eichmuller S, Woll E, Paulmichl M: Molecular and functional aspects of anionic channels activated during regulatory volume decrease in mammalian cells. Pflugers Archiv 2002;444:1-25.

-13 Jakab M, Furst J, Gschwentner M, Botta G, Garavaglia ML, Bazzini C, Rodighiero S, Meyer G, Eichmueller S, Woll E, Chwatal S, Ritter M, Paulmichl M: Mechanisms sensing and modulating signals arising from cell swelling. Cell Physiol Biochem 2002;12:235-258.

14 Shennan DB: Swelling-induced taurine transport: Relationship with chloride channels, anion-exchangers and other swelling-activated transport pathways. Cell Physiol Biochem 2008;21:15-28.

15 Jentsch TJ, Lutter D, Planells-Cases R, Ullrich F, Voss FK: VRAC: Molecular identification as LRRC8 heteromers with differential functions. Pflugers Arch 2016;468:385-393.

-16 Gutman GA, Chandy KG, Grissmer S, Lazdunski M, McKinnon D, Pardo LA, Robertson GA, Rudy B, Sanguinetti MC, Stuhmer W, Wang X: International union of pharmacology. LIII. Nomenclature and molecular relationships of voltage-gated potassium channels. Pharmacol Rev 2005;57:473-508.

17 Li Y, Um SY, McDonald TV: Voltage-gated potassium channels: Regulation by accessory subunits. Neuroscientist 2006;12:199-210.

18 DiCiommo DP, Duckett A, Burcescu I, Bremner R, Gallie BL: Retinoblastoma protein purification and transduction of retina and retinoblastoma cells using improved alphavirus vectors. Invest Ophthalmol Vis Sci 2004;45:3320-3329.

19 Kim JH, Lee SR, Li LH, Park HJ, Park JH, Lee KY, Kim MK, Shin BA, Choi SY: High cleavage efficiency of a $2 \mathrm{~A}$ peptide derived from porcine teschovirus-1 in human cell lines, zebrafish and mice. PLoS One 2011;6:e18556.

20 Meyer G, Rodighiero S, Guizzardi F, Bazzini C, Botta G, Bertocchi C, Garavaglia L, Dossena S, Manfredi R, Sironi C, Catania A, Paulmichl M: Volume-regulated $\mathrm{Cl}^{-}$channels in human pleural mesothelioma cells. FEBS Letters 2004;559:45-50.

-21 Dossena S, Maccagni A, Vezzoli V, Bazzini C, Garavaglia ML, Meyer G, Furst J, Ritter M, Fugazzola L, Persani L, Zorowka P, Storelli C, Beck-Peccoz P, Botta G, Paulmichl M: The expression of wild-type pendrin (SLC26A4) in human embryonic kidney (HEK 293 Phoenix) cells leads to the activation of cationic currents. Eur J Endocrinol 2005;153:693-699.

22 Gandini R, Dossena S, Vezzoli V, Tamplenizza M, Salvioni E, Ritter M, Paulmichl M, Furst J: LSm4 associates with the plasma membrane and acts as a co-factor in cell volume regulation. Cell Physiol Biochem 2008;22:579-590.

-23 Tamma G, Dossena S, Nofziger C, Valenti G, Svelto M, Paulmichl M: EGF stimulates IClswell by a redistribution of proteins involved in cell volume regulation. Cell Physiol Biochem 2011;28:1191-1202.

-24 Dossena S, Gandini R, Tamma G, Vezzoli V, Nofziger C, Tamplenizza M, Salvioni E, Bernardinelli E, Meyer G, Valenti G, Wolf-Watz M, Furst J, Paulmichl M: The molecular and functional interaction between ICln and HSPC038 proteins modulates the regulation of cell volume. J Biol Chem 2011;286:40659-40670.

-25 Kossler S, Nofziger C, Jakab M, Dossena S, Paulmichl M: Curcumin affects cell survival and cell volume regulation in human renal and intestinal cells. Toxicology 2012;292:123-135.

-26 Morabito R, Costa R, Rizzo V, Remigante A, Nofziger C, La Spada G, Marino A, Paulmichl M, Dossena S: Crude venom from nematocysts of Pelagia noctiluca (Cnidaria: Scyphozoa) elicits a sodium conductance in the plasma membrane of mammalian cells. Sci Rep 2017;7:41065.

27 Yan L, Figueroa DJ, Austin CP, Liu Y, Bugianesi RM, Slaughter RS, Kaczorowski GJ, Kohler MG: Expression of voltage-gated potassium channels in human and rhesus pancreatic islets. Diabetes 2004;53:597-607.

28 Bernardinelli E, Costa R, Nofziger C, Paulmichl M, Dossena S: Effect of known inhibitors of ion transport on pendrin (SLC26A4) activity in a human kidney cell line. Cell Physiol Biochem 2016;38:1984-1998.

29 Yang WP, Levesque PC, Little WA, Conder ML, Shalaby FY, Blanar MA: KvLQT1, a voltage-gated potassium channel responsible for human cardiac arrhythmias. Proc Natl Acad Sci U S A 1997;94:4017-4021.

-30 Yu SP, Kerchner GA: Endogenous voltage-gated potassium channels in human embryonic kidney (HEK293) cells. J Neurosci Res 1998;52:612-617.

31 Jiang B, Sun X, Cao K, Wang R: Endogenous Kv channels in human embryonic kidney (HEK-293) cells. Mol Cell Biochem 2002;238:69-79. 


\section{Cellular Physiology Cell Physiol Biochem 2018;45:867-882 \begin{tabular}{l|l|l|l} 
DOI: 10.1159/000487282 & $\begin{array}{l}\text { O } 2018 \text { The Author(s). Published by S. Karger AG, Basel } \\
\text { www.karger.com/cpb }\end{array}$
\end{tabular} \\ Costa et al.: Kv 3.1 and Chloride Channel Blockers}

-32 Gamper N, Fillon S, Huber SM, Feng Y, Kobayashi T, Cohen P, Lang F: IGF-1 up-regulates K+ channels via PI3kinase, PDK1 and SGK1. Pflugers Arch 2002;443:625-634.

33 Labro AJ, Priest MF, Lacroix JJ, Snyders DJ, Bezanilla F: Kv3.1 uses a timely resurgent K(+) current to secure action potential repolarization. Nat Commun 2015;6:10173.

-34 Yasuda T, Cuny H, Adams DJ: Kv3.1 channels stimulate adult neural precursor cell proliferation and neuronal differentiation. J Physiol 2013;591:2579-2591.

-35 Ho CS, Grange RW, Joho RH: Pleiotropic effects of a disrupted K+ channel gene: Reduced body weight, impaired motor skill and muscle contraction, but no seizures. Proc Natl Acad Sci U S A 1997;94:1533-1538.

-36 Grissmer S, Nguyen AN, Aiyar J, Hanson DC, Mather RJ, Gutman GA, Karmilowicz MJ, Auperin DD, Chandy KG: Pharmacological characterization of five cloned voltage-gated $\mathrm{K}^{+}$channels, types Kv1.1, 1.2, 1.3, 1.5, and 3.1, stably expressed in mammalian cell lines. Mol Pharmacol 1994;45:1227-1234.

37 Massengill JL, Smith MA, Son DI, O’Dowd DK: Differential expression of K4-AP currents and Kv3.1 potassium channel transcripts in cortical neurons that develop distinct firing phenotypes. J Neurosci 1997;17:3136-3147.

-38 Erisir A, Lau D, Rudy B, Leonard CS: Function of specific K(+) channels in sustained high-frequency firing of fast-spiking neocortical interneurons. J Neurophysiol 1999;82:2476-2489.

39 Lien CC, Jonas P: Kv3 potassium conductance is necessary and kinetically optimized for high-frequency action potential generation in hippocampal interneurons. J Neurosci 2003;23:2058-2068.

40 Ishikawa T, Nakamura Y, Saitoh N, Li WB, Iwasaki S, Takahashi T: Distinct roles of Kv1 and Kv3 potassium channels at the calyx of held presynaptic terminal. J Neurosci 2003;23:10445-10453.

41 Boda E, Hoxha E, Pini A, Montarolo F, Tempia F: Brain expression of Kv3 subunits during development, adulthood and aging and in a murine model of Alzheimer's disease. J Mol Neurosci 2012;46:606-615.

42 Hurlock EC, Bose M, Pierce G, Joho RH: Rescue of motor coordination by purkinje cell-targeted restoration of Kv3.3 channels in Kcnc3-null mice requires Kcnc1. J Neurosci 2009;29:15735-15744.

43 Shakkottai VG, do Carmo Costa M, Dell'Orco JM, Sankaranarayanan A, Wulff H, Paulson HL: Early changes in cerebellar physiology accompany motor dysfunction in the polyglutamine disease spinocerebellar ataxia type 3. J Neurosci 2011;31:13002-13014.

44 Pratt JA, Winchester C, Egerton A, Cochran SM, Morris BJ: Modelling prefrontal cortex deficits in schizophrenia: Implications for treatment. Br J Pharmacol 2008;153:S465-470.

45 Poirier K, Viot G, Lombardi L, Jauny C, Billuart P, Bienvenu T: Loss of function of KCNC1 is associated with intellectual disability without seizures. Eur J Hum Genet 2017;25:560-564.

46 Nascimento FA, Andrade DM: Myoclonus epilepsy and ataxia due to potassium channel mutation (MEAK) is caused by heterozygous KCNC1 mutations. Epileptic Disord 2016;18:135-138.

47 Muona M, Berkovic SF, Dibbens LM, Oliver KL, Maljevic S, Bayly MA, Joensuu T, Canafoglia L, Franceschetti S, Michelucci R, Markkinen S, Heron SE, Hildebrand MS, Andermann E, Andermann F, Gambardella A, Tinuper P, Licchetta L, Scheffer IE, Criscuolo C, Filla A, Ferlazzo E, Ahmad J, Ahmad A, Baykan B, Said E, Topcu M, Riguzzi P, King MD, Ozkara C, Andrade DM, Engelsen BA, Crespel A, Lindenau M, Lohmann E, Saletti V, Massano J, Privitera M, Espay AJ, Kauffmann B, Duchowny M, Moller RS, Straussberg R, Afawi Z, Ben-Zeev B, Samocha KE, Daly MJ, Petrou S, Lerche H, Palotie A, Lehesjoki AE: A recurrent de novo mutation in $K C N C 1$ causes progressive myoclonus epilepsy. Nat Genet 2015;47:39-46.

48 Oliver KL, Franceschetti S, Milligan CJ, Muona M, Mandelstam SA, Canafoglia L, Boguszewska-Chachulska AM, Korczyn AD, Bisulli F, Di Bonaventura C, Ragona F, Michelucci R, Ben-Zeev B, Straussberg R, Panzica F, Massano J, Friedman D, Crespel A, Engelsen BA, Andermann F, Andermann E, Spodar K, Lasek-Bal A, Riguzzi P, Pasini E, Tinuper P, Licchetta L, Gardella E, Lindenau M, Wulf A, Moller RS, Benninger F, Afawi Z, Rubboli G, Reid CA, Maljevic S, Lerche H, Lehesjoki AE, Petrou S, Berkovic SF: Myoclonus epilepsy and ataxia due to KCNC1 mutation: Analysis of 20 cases and $\mathrm{K}^{+}$channel properties. Ann Neurol 2017;81:677689.

49 Boddum K, Hougaard C, Xiao-Ying Lin J, von Schoubye NL, Jensen HS, Grunnet M, Jespersen T: Kv3.1/Kv3.2 channel positive modulators enable faster activating kinetics and increase firing frequency in fast-spiking gabaergic interneurons. Neuropharmacology 2017;118:102-112.

50 DeCoursey TE: Type 'l' (Kv3.1) K+ channels in lymphocytes. Cell Physiol Biochem 1997;7:7.

-51 Escobar LI, Martinez-Tellez JC, Salas M, Castilla SA, Carrisoza R, Tapia D, Vazquez M, Bargas J, Bolivar JJ: A voltage-gated K(+) current in renal inner medullary collecting duct cells. Am J Physiol Cell Physiol 2004;286:C965-974. 


\section{Cellular Physiology Cell Physiol Biochem 2018;45:867-882

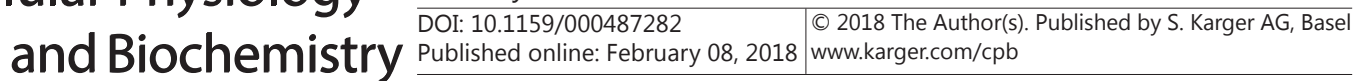 \\ Costa et al.: Kv 3.1 and Chloride Channel Blockers}

52 Krause E, Pfeiffer F, Schmid A, Arndts D, Schulz I: LOE 908 blocks delayed rectifier type potassium channels in PC12 cells and cortical neurons in culture. Biochem Biophys Res Commun 1998;244:659-664.

53 Perney TM, Marshall J, Martin KA, Hockfield S, Kaczmarek LK: Expression of the mRNAs for the Kv3.1 potassium channel gene in the adult and developing rat brain. J Neurophysiol 1992;68:756-766.

54 Rudy B, Chow A, Lau D, Amarillo Y, Ozaita A, Saganich M, Moreno H, Nadal MS, Hernandez-Pineda R, Hernandez-Cruz A, Erisir A, Leonard C, Vega-Saenz de Miera E: Contributions of Kv3 channels to neuronal excitability. Ann N Y Acad Sci 1999;868:304-343.

55 Vojtisek O, Kankova D, Pavelka K, Handlova D: Comparison of the effects of niflumic acid and aloxiprin in patients with progressive chronic rheumatoid arthritis in a double blind trial. Arzneim Forsch 1975;25:1308-1311.

56 Cremonesi G, Cavalieri L: Efficacy and safety of morniflumate for the treatment of symptoms associated with soft tissue inflammation. J Int Med Res 2015;43:290-302.

57 Scott RH, Sutton KG, Griffin A, Stapleton SR, Currie KP: Aspects of calcium-activated chloride currents: A neuronal perspective. Pharmacol Ther 1995;66:535-565.

58 Fuller CM, Ji HL, Tousson A, Elble RC, Pauli BU, Benos DJ: Ca(2+)-activated Cl(-) channels: A newly emerging anion transport family. Pflugers Arch 2001;443:S107-110.

59 Sanders KM, Zhu MH, Britton F, Koh SD, Ward SM: Anoctamins and gastrointestinal smooth muscle excitability. Exp Physiol 2012;97:200-206.

60 Dossena S, Vezzoli V, Cerutti N, Bazzini C, Tosco M, Sironi C, Rodighiero S, Meyer G, Fascio U, Furst J, Ritter M, Fugazzola L, Persani L, Zorowka P, Storelli C, Beck-Peccoz P, Botta G, Paulmichl M: Functional characterization of wild-type and a mutated form of SLC26A4 identified in a patient with Pendred syndrome. Cell Physiol Biochem 2006;17:245-256.

61 Maleeva G, Peiretti F, Zhorov BS, Bregestovski P: Voltage-dependent inhibition of glycine receptor channels by niflumic acid. Front Mol Neurosci 2017;10:125.

62 Sinkkonen ST, Mansikkamaki S, Moykkynen T, Luddens H, Uusi-Oukari M, Korpi ER: Receptor subtypedependent positive and negative modulation of GABA(A) receptor function by niflumic acid, a nonsteroidal anti-inflammatory drug. Mol Pharmacol 2003;64:753-763.

63 Lerma J, Martin del Rio R: Chloride transport blockers prevent N-methyl-D-aspartate receptor-channel complex activation. Mol Pharmacol 1992;41:217-222.

-64 Balderas E, Ateaga-Tlecuitl R, Rivera M, Gomora JC, Darszon A: Niflumic acid blocks native and recombinant T-type channels. J Cell Physiol 2012;227:2542-2555.

65 Jang DJ, Park JS, Ko HR, Jee JP, Kim JK, Kim ST, Kim CK: Simultaneous determination of niflumic acid and its prodrug, talniflumate in human plasma by high performance liquid chromatography. Biomed Chromatogr 2005;19:32-35.

66 Kim H, Han, YH, Chung, SJ, Lee, MH, Shim, CG: Pharmacokinetics of talniflumate, a prodrug of niflumic acid, following oral administration to man. Arch Pharm Res 1996;19:5. 